\title{
Cytogenetics in oncology: From hematologic malignancies to solid tumors
}

\author{
Fransiska Hardi ${ }^{1}$, Aru W. Sudoyo ${ }^{2}$ \\ 1 Department of Internal Medicine, Faculty of Medicine, University of Indonesia/Dr. Cipto Mangunkusumo Hospital, Jakarta, Indonesia \\ 2 Division of Hematology and Medical Oncology, Department of Internal Medicine, Faculty of Medicine, University of Indonesial \\ Dr. Cipto Mangunkusumo Hospital, Jakarta, Indonesia
}

\begin{abstract}
Abstrak
Walaupun saat ini kanker dikenal sebagai penyakit yang berkaitan dengan lingkungan dan muncul secara sporadis, namun kanker dipertimbangkan sebagai suatu penyakit genetik karena adanya mutasi gen sebagai faktor yang konsisten. Kromosom Philadelphia yang ditemukan pada pasien-pasien leukemia granulositik kronik (LGK) merupakan penemuan kelainan kromosom bermakna pertama yang berkaitan dengan jenis keganasan tertentu. Berawal dari penemuan ini, sitogenetika yang mempelajari kromosom telah menjadi perangkat yang berharga dalam penatalaksanaan kanker - membantu penegakan diagnosis, panduan terapi, dan petanda prognosis. Pada kegananasan hematologi, kelainan kromosom sebagian besar ditemukan pada sumsum tulang, dan penemuan tersebut lebih patognomonik. Keadaan yang berbeda ditemukan pada tumor padat, dimana saat tumor terlihat dengan mata telanjang telah terjadi perubahan kromosom yang kompleks sehingga menimbulkan kesulitan teknis bagi para ahli sitogenetika. Namun para ilmuwan percaya bahwa adanya kemajuan dalam teknologi kromosom, dari sitogenetika konvensional menjadi sitogenetika molekuler, akan menyediakan informasi lebih lanjut, berkaitan dengan tumor padat. (Med J Indones 2009; 18: 69-75)
\end{abstract}

\begin{abstract}
Although presently known as an environmentally-related disease and appears mostly sporadic, cancer is regarded as a genetic disease based on the presence of genetic mutation as a consistent factor. The "Philadelphia Chromosome" found consistently among chronic myeloid leukemia (CML) patients was the first significant finding of a chromosomal abnormality specifically related to a particular disease. Starting from this point, cytogenetics as the study of chromosomes has become a valuable tool in the assessment of cancer - as an aid in diagnosis, thus guiding therapy, and as a prognostic marker. Chromosomal abnormalities are found mostly in hematological malignancies and the findings are more pathognomonic. The situation is different in solid tumors, which when visible to the naked eye already have complex chromosomal changes and thus pose technical difficulties to the cytogeneticist. However, the scientists believe that the shift in chromosomal studies from conventional cytogenetics to molecular cytogenetics will provide further information regarding solid tumors. (Med J Indones 2009; 18: 69-75)
\end{abstract}

Keywords: Philadelphia chromosome, FISH, chronic myeloid leukemia

Remarkable progress has occurred in the fields of cancer genetics and cytogenetics since the first report regarding a chromosomal abnormality subsequently known as the "Philadelphia $(\mathrm{Ph})$ chromosome" in a patient with chronic myeloid leukemia (CML) in 1960. This was the first consistent chromosome abnormality in human cancer. Additional chromosomal changes associated with various hematological malignancies followed in 1970s after the introduction of chromosome banding technique. ${ }^{1,2}$ Besides this conventional cytogenetics, now the field still grows rapidly with the advent of molecular cytogenetics techniques, such as fluorescent in situ hybridization (FISH), multicolour FISH, spectral karyotyping, comparative genomic hybridization, and other molecular techniques followed.

The finding of chromosomal abnormalities in cancer will improve the management of patient. The present review focused on the role of cytogenetics in hematological malignancies and solid tumor. 


\section{CYTOGENETICS}

Before chromosomal abnormalities in cancer are discussed, we will take a brief overview of human cytogenetics. Cytogenetics is the study of chromosomes and the related diseases caused by abnormal chromosome number and/or structure. Normally chromosomes can notbe seen with a light microscope, but during metaphase or late prophase they become condensed enough to be analyzed. To ensure that any abnormalities detected represent in vivo conditions, direct preparations and short term cultures are usually preferred. ${ }^{1,3}$

Human chromosome nomenclature is based on an International System for Human Cytogenetic Nomenclature/ISCN (1985). The normal human somatic cells have 46 chromosomes that include 22 pairs of autosomes and two sex chromosomes, $\mathrm{XX}$ in female and $\mathrm{XY}$ in male (figure 1). This is called the diploid number. After the discovery of banding technique, each human chromosome can be precisely identified on the basis of its unique banding pattern. ${ }^{4}$

Under the microscope chromosomes appear as thin, thread-like structures. They have a short arm designated as $\mathrm{p}$, and a long arm as $\mathrm{q}$ which are separated by a primary constriction called the centromere. Each chromosome arm consists of one or more regions. Each region composed of one or more bands. A band is defined as chromosomal area that is distinguishable from adjacent segment by appearing darker or lighter by one or more banding techniques. In allocating any particular band, four items are therefore required: the chromosome number, the arm symbol, the region number, and the band number within the region. For example 1q23 means chromosome 1, the long arm, region 2 , and band $3 ., 4$

Although chromosome abnormalities can be very complex, there are two basic types, numerical and structural. Both types can occur concurrently. Numerical abnormalities involve the loss and/or gain of a whole chromosome and can include both autosomes and sex chromosomes. ${ }^{4}$ The abbreviation used are $(+)$ for gained or (-) for lost of chromosome. Cells which have lost a chromosome are monosomy, while those with an extra chromosome are trisomy. There is also a condition called triploidy in which there is an extra copy of every chromosome. Occasionally, an individual carries an extra chromosome which can't be identified by its banding pattern, these are called marker chromosome (mar). The introduction of FISH techniques has been a valuable tool in the identification of marker chromosomes. ${ }^{5}$

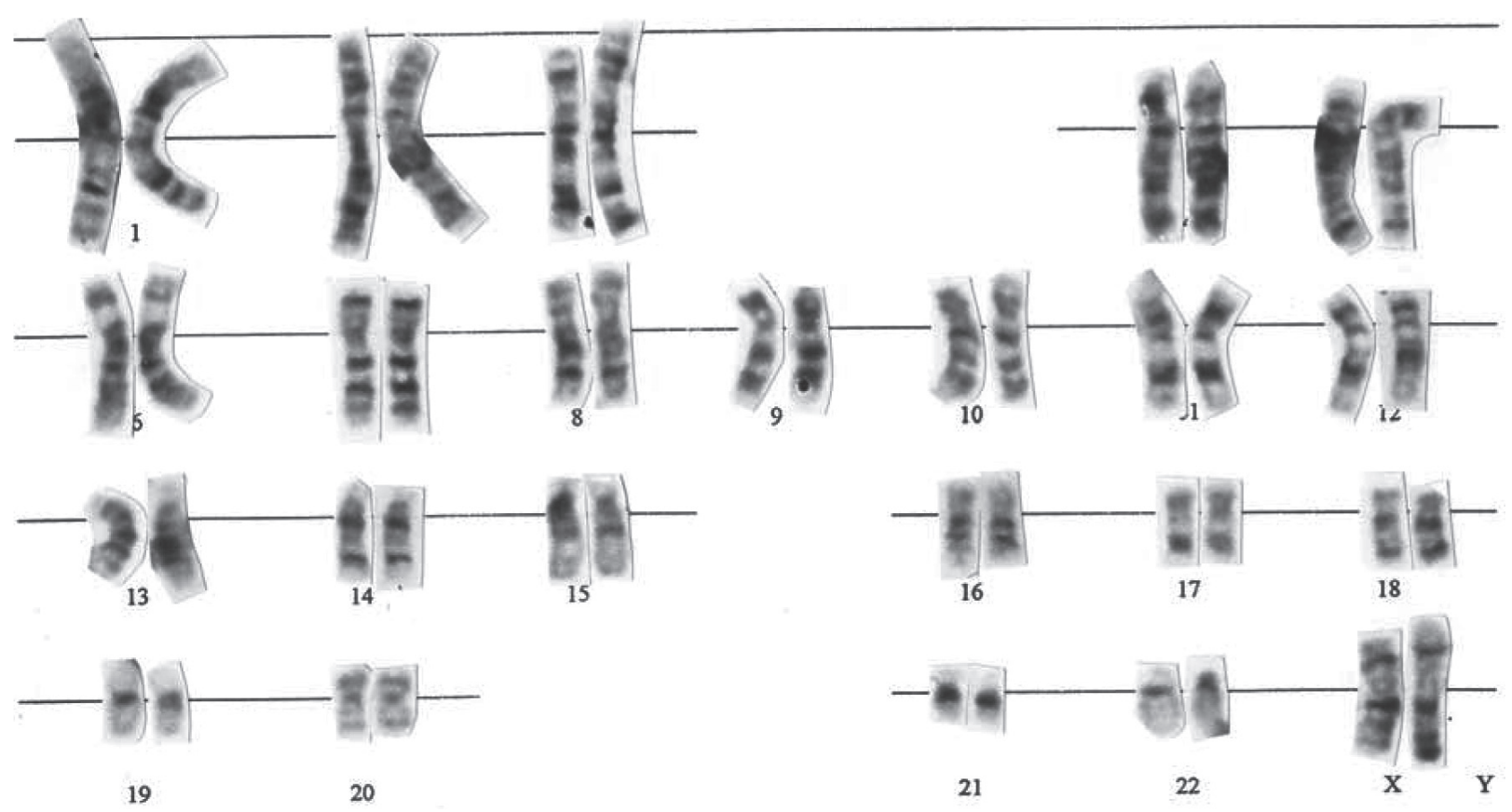

Figure 1. Normal male karyotype: it consists of 22 pairs of autosome and 2 sex chromosomes (XY) 
Structural abnormalities include translocations, deletions, inversions, and insertions. Translocation (t) occurs when two or more chromosomes exchange material. This exchange may or may not be reciprocal. The Philadelphia $(\mathrm{Ph})$ chromosome, a cytogenetic change seen in chronic myeloid leukemia (CML) provides the classic example of a cancer-associated translocation., ${ }^{4,6}$

Deletion (del) means loss of chromosomal material. These chromosomal deletions may lead to neoplastic development when a tumor suppressor gene is lost, such as in epithelial adenoma. ${ }^{6}$

Inversion (inv) designates a $180^{\circ}$ rotation of a chromosome segment. Insertion (ins) means a chromosomal material moves to a new, interstitial position in the same or another chromosome. These two abnormalities may cause an abnormal juxtaposition of genetic materials that can lead to the formation of abnormal proteins that can initiate neoplasia. ${ }^{6}$ Examples of chromosomal abnormalities can be seen in figure 2 .

Flourescent in situ hybridization (FISH) is a technology using fluorescent labeled DNA probes to detect or confirm gene or chromosome abnormalities that are generally beyond the resolution of conventional cytogenetics. ${ }^{5,7}$ When the mitotic index is low, or the cytogenetics preparation suboptimal, an accurate diagnosis often cannot be achieved using standard banding. ${ }^{4,7}$ In this situation FISH can be useful because FISH methodology allows the detection of specific targets not only in metaphase spreads, but also on nondividing interphase nuclei., ${ }^{4,7}$ This makes FISH as a powerful tool for a rapid and sensitive detection of chromosome abnormalities.

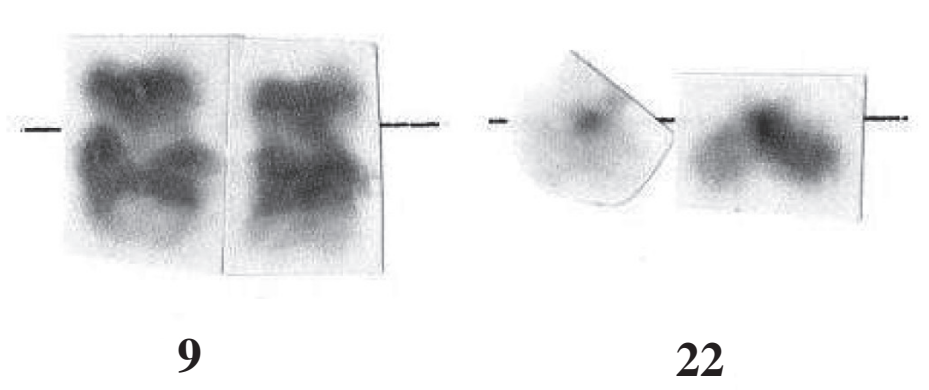

(a) $\mathbf{t}(9 ; 22)$

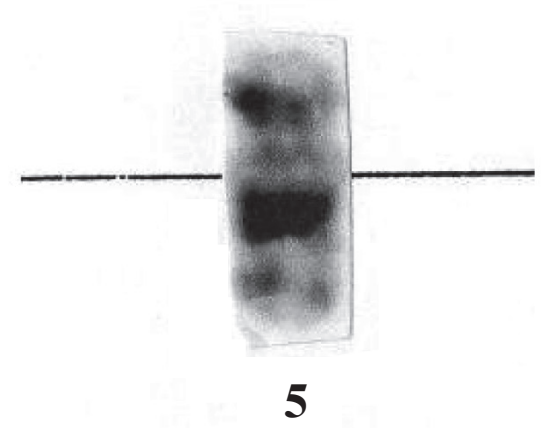

(c) -5

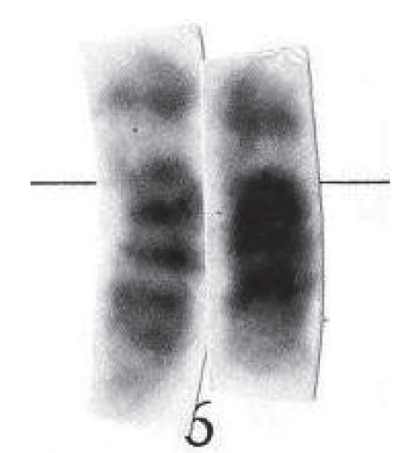

(b) $\operatorname{del}(6 q)$

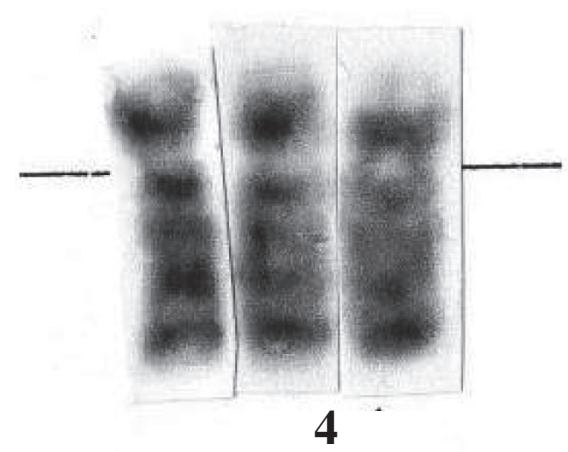

(d) +4 


\section{Chromosomal abnormalities in cancer}

Cancer, in its various forms is a genetic disease. ${ }^{4}$ This comes from the finding of chromosomal abnormalities in cancer. These abnormalities may arise as a consequence of random replication errors; exposure to carcinogens; or damaged DNA repair processes. Three genes that contribute to malignancy are oncogenes, tumor suppressor genes, and DNA repair genes. Genes that promote normal cell growth (protooncogenes) can be converted to oncogens due to point mutation, amplification, or dysregulation. Genes that restrain growth are tumor suppressor genes; therefore unregulated cell growth arises if their function is lost. ${ }^{4}$

Almost all cancers originate from a single progenitor cell, that forms a clone. It can be concluded as a clonal origin when numbers of cells have the same or closely related abnormal chromosome complements. In the development of cancer, the mutations can occur through multistage processes to change a normal cell into a malignant one. In this process, subclones may have evolved so the clones are not necessarily homogenous. ${ }^{4}$

Chromosomal changes in cancer are significant if the changes are non random. When there is an abnormality in a chromosome, it has to be determined whether it's accidentally happened (random) or not. Another important thing in examining cancer chromosome changes is to find out whether the abnormalities are primary or secondary. Primary aberrations are frequently found as a solitary abnormality and unique for a particular tumor type. This primary aberration is usually already detected at the time a cancer is diagnosed. This fact shows that the changes are related to carcinogenesis. Conversely, secondary aberrations found in later stage of cancers particularly solid tumors, and therefore are not important in the initiation of the disease. ${ }^{6,8}$

\section{Cytogenetics in hematological malignancies}

The relative ease in obtaining samples and the advances in cytogenetics make chromosome studies in hematological malignancies have grown rapidly. Nowadays cytogenetic analysis has become an integral part of diagnosis, therapy option, and prognostic value in hematological malignancies.

To detect chromosomal changes associated with hematological malignancies, bone marrow is the optimal source for affected cells. When necessary, blood cells can be examined, but the success rate for this analysis is low and the information obtained is less than optimal. ${ }^{6}$ Common chromosomal changes in hematological malignancies can be found in table 1 .

Table 1. Common chromosomal abnormalities in hematological malignancies ${ }^{1,7}$

\begin{tabular}{ll}
\hline \multicolumn{1}{c}{ Hematological Malignancy } & \multicolumn{1}{c}{ Common chromosomal abnormalities } \\
\hline Chronic myeloid leukemia & $\mathrm{t}(9 ; 22)(\mathrm{q} 34 ; \mathrm{q} 11)$ \\
Chronic myeloid leukemia in blast crisis & $+8,+\mathrm{Ph},+19, \mathrm{i}(17 \mathrm{q})$ \\
Acute myeloid leukemia & $\mathrm{t}(8 ; 21)$, inv $(16), \mathrm{t}(15 ; 17),-5 /$ del5q, -7, abn $(3 \mathrm{q})$ \\
Myelodisplastic syndrome (MDS) & $\operatorname{del}(5 \mathrm{q})$, monosomy 7, monosomy 8, complex karyotype \\
Secondary acute leukemia proceed by MDS & $5 \mathrm{q}-/-5,7 \mathrm{q}-/-7, \operatorname{del}(20 \mathrm{q})$ \\
Burkitt lymphoma & $\mathrm{t}(8 ; 14)(\mathrm{q} 24 ; \mathrm{q} 32), \mathrm{t}(8 ; 22)(\mathrm{q} 24 ; \mathrm{q} 11), \mathrm{t}(2 ; 8)(\mathrm{p} 12 ; \mathrm{q} 24)$ \\
Hodgkin's disease & Structural changes of chromosome 1 and 11, 6q-, 14q+, trisomy \\
\end{tabular}


Chronic myeloid leukemia (CML) was the first hematological malignancy known related to chromosome abnormalities, as a consequence of furious and diligent work by researchers from all over the world and first reported by Janet Rowley from Chicago. The reciprocal translocation $\mathrm{t}(9 ; 22)(\mathrm{q} 34 ; \mathrm{q} 11)$ in $\mathrm{CML}$, called Philadelphia chromosome $(\mathrm{Ph})$ became clinically important as it is associated to patient's survival. It is well established that patients with the $\mathrm{Ph}$ chromosome have a much longer median survival than patients who are $\mathrm{Ph}$ negative. Subsequent work in molecular genetics has revealed that the $\mathrm{Ph}$ translocation causes fusion of gene sites that code for the break cluster region (BCR) and the avian blastic leukemia (ABL) proteins. ${ }^{9}$ The BCR analysis (Southern blotting) is indicated in cases having the $\mathrm{Ph}$ chromosome as it is too small to be identified with conventional cytogenetics. It is to differentiate $\mathrm{Ph}^{+}$acute leukemia (particularly acute lymphoblastic leukemia) from CML, and to followup CML patients during therapy or after bone marrow transplantation. Moreover, as the disease progresses, additional chromosomal anomalies e.g. $+8,+\mathrm{Ph},+19$, and $\mathrm{i}(17 \mathrm{q})$, may precede the development of blast crisis before the manifestations become clinically apparent. ${ }^{6}$

In acute leukemia, the determination of the chromosomal changes serves as a diagnostic tool to predict clinical and prognostic aspects of a case, to choose appropriate therapy, and to determine the presence or absence of a complete remission. ${ }^{6}$

Generally, in acute myeloid leukemia (AML), analysis of chromosome abnormalities allows categorization of risk groups. Chromosomal abnormalities such as $\mathrm{t}(8 ; 21)$, inv(16), and $\mathrm{t}(15 ; 17)$ present significantly better prognosis, whereas aberration such as $-5 / \operatorname{del}(5 q)$, -7 , abn ( $3 q)$, and complex karyotype are associated with a high risk for induction failure, relapse, and shortened survival. ${ }^{10}$ Cheson et al, (2003) recommended the use of cytogenetic remission (CRc) as a part of the criteria for complete remission (CR). Research by Marcucci et al, (2004) on adult AML patients suggests that conversion to normal karyotype at the time of the first $\mathrm{CR}$ is an important prognostic indicator for clinical outcome. ${ }^{11}$

In patients aged 60 years or older, the prognosis of AML is extremely poor. Besides the advance age, another features such as increased incidence of primary drug resistance, antecedent myelodysplasia, and karyotipic abnormalities are known to be associated with poor outcome. Despite the generally bad prognosis, a small number of long term survivors exist among patients treated with current standard chemotherapy. Hence it is important to determine whether the patient belongs to this group or not. Observation by Farag et al. (2006) concluded that pretreatment cytogenetics adds informations to other factors in older AML patient. Patient with at least 5 abnormalities appear to benefit minimally from current treatment and are better suited for investigational therapy or supportive care. ${ }^{12}$

Cytogenetic studies in myelodysplastic syndromes (MDS) may have pathogenetic, diagnostic, and prognostic implications. The most frequent abnormalities found in MDS are del(5q), monosomy 7 , trisomy 8 , and complex karyotype. ${ }^{13}$ Conventional cytogenetics methods are routinely used to detect karyotypic abnormalities in bone marrow cells of MDS patient. Identification of the origin of aberrant or marker chromosome could be done by combining FISH and immunophenotypic or cytochemistry analyses. ${ }^{14}$

Secondary acute leukemia is often preceded by an MDS. This condition is often associated with specific chromosomal changes, the most common are $5 \mathrm{q}-/-5,7 \mathrm{q}-$ $/-7$, and del(20q). Since the cytogenetic findings in this condition are generally diagnostic and prognostic (e.g., $5 \mathrm{q}$ - is associated with a relatively good prognosis, and -7 with poor prognosis), cytogenetic examination of the bone marrow is an important step in the management of this state. ${ }^{6}$

\section{Cytogenetics in solid tumors}

Although solid tumors, particularly carcinoma, play larger part in human morbidity and mortality, cytogenetics of solid tumors develop more slowly than those of hematological malignancies. This situation happens because of several technical limitations. Firstly, the chromosome quality in solid tumors is often suboptimal due to necrotic samples that result in destruction of cancer cells before culturing. Second, in contrast to hematological malignancies, which often contain few cytogenetic changes, most solid tumors have multiple and complex chromosomal changes acquired during tumor progression, which cause difficulties in identifying the primary chromosome changes associated with the specific tumor type. Third, low mitotic index in short term culture of cancer cell that is necessary to avoid overgrowth by normal stromal or supporting cells. ${ }^{10,17}$ In recent years, the development of cytogenetic technique e.g. FISH has led to the description of specific chromosome abnormalities in 
solid tumor because it can be performed on fresh tumor tissue, exfoliative cells, and embedded specimen. ${ }^{16-18}$

The complexity of chromosomal changes in solid tumor can be associated with multistage cascade of genetic changes. According to this concept, the initial genetic change leads to an increase in cell growth, which is followed by a series of changes that consequently result in malignant transformation and metastatic spread. Example for this condition is tumor of epithelial origin, including breast cancer, colon cancer, and bladder cancer. ${ }^{6,8,15}$ Common chromosomal abnormalities in solid tumors can be seen in table 2 .

In clinical oncology, cytogenetics for solid tumor are used in diagnosis, evaluation of treatment response of metastatic cancer, and as marker for prognosis and targeted therapy. ${ }^{17,19}$ In tumors in which histologic features overlap, cytogenetics plays an important role in diagnosis, for example the $\mathrm{t}(12 ; 16)$ in myxoid liposarcoma, the $\mathrm{t}(2,13)$ in alveolar rhabdomyosarcoma, and the $\mathrm{t}(\mathrm{X} ; 18)$ in synovial sarcoma. These conditions are also related to a rational approach of therapy. In surgical cases, cytogenetics has been used to monitor the surgical margin in head and neck carcinoma that is able to identify subclinical tumorigenesis. ${ }^{17}$

In metastatic cancer, molecular cytogenetics can accurately monitor tumor response to therapy by the detection of chromosomal aneusomy in cerebrospinal fluid, so that the clinician can change ineffective therapy at an earlier stage in the course of treatment. ${ }^{17}$
Molecular cytogenetics, particularly dual color FISH assay has proven to be as effective as a prognostic marker and predictor for the response to therapy in breast cancer patients by detection of HER-2 gene amplification in tumor cells. Overexpression of HER-2 has been found in $20-30 \%$ of breast cancers and has been associated with a poor overall survival. ${ }^{17}$

Detection of residual disease in patient with solid malignancies is essential, and FISH technology answers this aim. Interphase FISH application can detect tumor cells in body fluids through non-invasive procedures. Urinary cytology, for illustration, has been the reference test for the evaluation of symptomatic patients, detection of lesions in high-risk patients, and follow-up of patients with prior history of transitional cell carcinoma. ${ }^{17,19}$

In conclusion, non random chromosomal abnormalities are found in various types of cancer. These conditions brought cytogenetics as a tool for diagnostic, therapy, and prognostic marker in the field of oncology. The development of conventional technology into molecular cytology has led to prompt development of cancer cytogenetics.

\section{REFERENCES}

1. Heim S, Mitelman F. Cancer cytogenetics. $2^{\text {nd }}$ ed. New York: Alan R Liss Inc; 1995. p.13-28, 203-20, 229.

Table 2. Common chromosomal abnormalities in solid tumors ${ }^{1,7}$

\begin{tabular}{ll}
\hline \multicolumn{1}{c}{ Solid tumors } & \multicolumn{1}{c}{ Common chromosomal abnormalities } \\
\hline Ewing sarcoma & $\mathrm{t}(11 ; 22)(\mathrm{q} 24 ; \mathrm{q} 12)$ \\
Kidney carcinoma & $\operatorname{del}(3)(\mathrm{p} 11-21), \mathrm{t}(5 ; 14)(\mathrm{q} 13 ; 22)$ \\
Small cell lung cancer & $\operatorname{del}(3)(\mathrm{p} 14 \mathrm{p} 23)$ \\
Meningioma & $\operatorname{monosomy~} 22$ \\
Myxoid liposarcoma & $\mathrm{t}(12 ; 16)(\mathrm{q} 13-14 ; \mathrm{p} 11)$ \\
Prostatic carcinoma & $\operatorname{del}(7)(\mathrm{q} 22), \operatorname{del}(10)(\mathrm{q} 24)$ \\
Breast carcinoma & $\operatorname{del}(1)(\mathrm{p} 35), \operatorname{del}(3 \mathrm{p}), \operatorname{del}(16 \mathrm{q}), 17 \mathrm{q}-$ \\
Willms' tumor & $\operatorname{structural~changes~of~1,~del(11)(p13)~}$ \\
Malignant melanoma & $\operatorname{del}(1)(\mathrm{p} 12-22), \mathrm{t}(1 ; 19)(\mathrm{q} 12 ; \mathrm{p} 13)$, del $(6 \mathrm{q})$, trisomy 7 \\
Colon cancer & structural changes of chromosomes $1,17,18,+7,+12$, del $(5 \mathrm{q})$, del $(10 \mathrm{q})$ \\
\hline
\end{tabular}


2. Glassman AB. Cytogenetics, in situ hybridization and molecular approaches in the diagnosis of cancer. Ann Clin Lab Sci. 1998;28(6):324-30.

3. Ried T. Cytogenetics - In color and digitalized. N Engl J Med. 2004; 350(16):1597-600.

4. Braunwald E, Fauci AS, Kasper DL, Hauser SL, Longo DL, Jameson JL, editors. Harrison's Principles of Internal Medicine. 15 $5^{\text {th }}$ ed. New York: McGraw-Hill; 2001.

5. Mark HFL, Przygoda JJ, Sikoy W. Fluorescent in situ hybridization for identifying cytogenetic abnormalities in inadequate and suboptimal specimens. Pathobiology. 1998;66:216-20.

6. Sandberg AA. Cancer cytogenetics for clinicians. CA Cancer J Clin. 1994;44(3):136-59.

7. Hackel C, Varella-Garcia M. Interphase cytogenetics using fluorescence in situ hybridization: an overview of its application to diffuse and solid tissue. Braz J Genet. 1997;20(1):97-106.

8. Cin PD, Trent JM. What should oncologists know about cytogenetics in solid tumors? Ann Oncol. 1993; 4(10): $821-4$

9. Glassman AB. Cytogenetics, gene fusion, and cancer. Ann Clin Lab Sci. 1995;25(5):389-93.

10. Frohling S, Schlenk RF, Kayser S, Morhardt M, Benner A, Dohner $\mathrm{K}$ et al. Cytogenetics and age are major determinants of outcome in intensively treated acute myeloid leukemia patients older than 60 years: results from AMLSG trial AML HD98-B. Blood. 2006;108(10):3280-8.

11. Marcucci G, Mrózek K, Ruppert A, Archer KJ, Pettenati MJ, Heerema NA et al. Abnormal cytogenetics at date of morphologic complete remission predicts short overall and disease-free survival, and higher relapse rate in adult acute myeloid leukemia: results from cancer and leukemia group B study 8461. J Clin Oncol. 2004;22(12):2410-8.

12. Farag SS, Archer KJ, Mrozek K, Ruppert AS, Carroll AJ, Vardiman JW, Pettenati MJ et al. Pretreatment cytogenetics add to other prognostic factors predicting complete remission and long-term outcome in patients 60 years of age or older with acute myeloid leukemia: results from Cancer and Leukemia Group B 8461. Blood. 2006;108(1):63-73.

13. Vallespi T, Imbert M, Mecucci C, Preudhome C, Fenaux P. Diagnosis, classification, andcytogeneticsofmyelodysplastic syndromes. Haematologica. 1998;83(3):258-75.

14. Sun G, Lorenzo M, Tripodi J, Chrysostomou C, Stephenson $\mathrm{CF}, \mathrm{McGill}$ JR et al. Valuation of cytogenetics and FISH in evaluation of myelodysplastic syndromes: A cancer cytogenetics reference lab's experience. Blood. 2004;104 (Suppl): 1441.

15. Sandberg AA, Turc-Carel C. The cytogenetics of solid tumors - Relation to diagnosis, classification and pathology. Cancer. 1987;59(3):387-95.

16. Cordon-Cardo C. Applications of molecular diagnostics: Solid tumor genetics can determine clinical treatment protocols. Mod Pathol. 2001;14(3):254-7.

17. Varella-Garcia M. Molecular cytogenetics in solid tumors: Laboratorial tool for diagnosis, prognosis, and therapy. Oncologist. 2003;8(1):45-58.

18. Fiegl M, Zojer N, Kaufmann H, Drach J. Clinical application of molecular cytogenetics in solid tumors. Onkologie. 1999;22:114-20.

19. N, Triaspolitica. "Mengenal Penyakit Kanker, Jenis, Gejala, Penyebab Berikut Pengobatan Kanker." Mau Nanya Dong Dok. N.p, 20 June 2017. Web. 28 June 2017. $<$ https://nanyadongdok.blogspot.com/2017/06/mengenalpenyakit-kangker-jenis-gejala.html $>$. 